\title{
Analysis of cyclic feed intake in rats fed on a zinc-deficient diet and the level of dihydropyrimidinase (EC 3.5.2.2)
}

\author{
BY NANAYA TAMAKI, SHIGEKO FUJIMOTO-SAKATA, MARIKO \\ KIKUGAWA, MASAE KANEKO AND SATOMI ONOSAKA \\ Faculty of Nutrition, Kobe Gakuin University, Arise, Igawadani, Nishi-ku, Kobe 651-21, Japan \\ AND TATSUYA TAKAGI \\ Genome Information Research Center, Osaka University, Yamadaoka 3-1, Suita 565, Japan
}

(Received 6 June 1994 - Revised 4 August 1994-Accepted 24 August 1994)

\begin{abstract}
The body weight and feed intake of rats fed on a $\mathrm{Zn}$-deficient diet for $28 \mathrm{~d}$ were reduced compared with those of control rats. The feed intakes of the $\mathrm{Zn}$-deficient and control groups during the period were $10 \cdot 2$ (SE 0-3) and 15-7 (SE 0.2) g/d respectively. Cyclic variations in feed intake and body-weight changes were found in analysis not only of all the data for five rats but also that in each individual rat. Cosinor analysis revealed that the cyclical period of both the feed intake and body-weight change in the $\mathrm{Zn}$-deficient rats was 3.5 (SE 0.1) d. The mesor and amplitude value of the feed intake in the $\mathrm{Zn}$-deficient rats was $10 \cdot 1$ (SE 0.4) $\mathrm{g} / \mathrm{d}$ and 3.5 (SE 0.5) $\mathrm{g} / \mathrm{d}$ respectively, and that of body-weight change was 1.4 (SE 0.1 ) g/d and 7.9 (SE 1.3) g/d respectively. Among pyrimidine-catabolizing enzymes, dihydropyrimidinase (EC 3.5.2.2) activity showed significant retardation in the $\mathrm{Zn}$-deficient rat liver with decrease of the enzyme protein. The ratio of apo-form to holo-form dihydropyrimidinase in the liver was not affected by the Zn-deficient diet.
\end{abstract}

Zinc deficiency: Cosinor analysis: Dihydropyrimidinase

It is well recognized that $\mathrm{Zn}$ is essential for growth in animals (Williams \& Mills, 1970) as well as man (Golden, 1988). Failure of growth during $\mathrm{Zn}$ deficiency in vivo is complex, with cyclical changes in feed intake (Mills et al. 1969; Chesters \& Quarterman, 1970; Chesters \& Will, 1973; Wallwork et al. 1981; Gingliano \& Millward, 1984; Kramer et al. 1984; Quinn et al. 1990), body weight (Wallwork et al. 1981; Gingliano \& Millward, 1984), and muscle mass (Gingliano \& Millward, 1984). Zn deficiency impairs growth by a combination of decreased feed intake, lowered anabolic response to the feed, and increased catabolic response (Gingliano \& Millward, 1984). Recently, it was proposed that metabolic hormones such as insulin, somatotropin, insulin-like growth factor, and corticosterone may be mediating factors in the impaired growth (Gingliano \& Millward, 1987; Droke et al. 1993).

Dihydropyrimidinase (5,6-dihydropyrimidine amidohydrolase, EC 3.5.2.2) is the second enzyme in pyrimidine catabolism. Mammalian dihydropyrimidinase was originally studied (Wallach \& Grisolia, 1957), purified and characterized in calves (Maguire \& Dudley, 1978; Kautz \& Schnackerz, 1989), cows (Brooks et al. 1983; Lee et al. 1986, 1987), and rats (Maguire \& Dudley, 1978; Kikugawa et al. 1994).

Dihydropyrimidinase is a tetramer and a $\mathrm{Zn}$-metalloenzyme (Brooks et al. 1979, 1983). The $\mathrm{Zn}$ cation can be removed by incubation with the chelators $O$-phenanthroline, 8hydroxyquinoline-5-sulphonic acid, or dipicolinic acid, yielding an inactive apoenzyme (Brooks et al. 1979, 1983; Lee et al. 1986). The enzyme activity can be restored by 
incubating the apoenzyme with $\mathrm{Zn}$ (Brooks et al. 1979). Zn also effectively inhibits the enzyme activity with a $K_{\mathrm{i}}$ of $23 \cdot 1 \mu \mathrm{M}$ (Kikugawa et al. 1994). These results suggest that $\mathrm{Zn}$ acts as an inhibitor as well as an activator of the enzyme activity.

In the present study, we calculated the period of the cycle of feed intake in rats on a Zndeficient diet by cosinor analysis. We also found that a $\mathrm{Zn}$-deficient diet results in decrease of rat liver dihydropyrimidinase with diminution of the enzyme protein.

\section{MATERIALS AND METHODS}

\section{Animals and diets}

Male albino rats (Wistar strain, weighing $100-110 \mathrm{~g}$ ) were housed in individual screenbottomed cages in a room maintained at $23 \pm 1^{\circ}$ with $50 \%$ humidity, under controlled lighting conditions (lights on 07.00 to 19.00 hours and lights off 19.00 to 07.00 hours, local time). The animals were fed on a commercial stock diet (Oriental Yeast Ltd., Tokyo, Japan) and water $a d l i b$. for 1 week before the experiment to acclimate them to the new environment. Acclimated rats showing progressive weight gain were selected and separated into groups. Body weight and feed intake were determined daily at 09.00 to 10.00 hours. Ten rats were assigned to each experimental group. The rats were given the experimental diet for 4 weeks and killed between 09.00 and 11.00 hours on day 28 under anaesthesia with diethyl ether.

Blood samples were collected into plain glass tubes and stored at $4^{\circ}$ overnight until centrifugation at $1500 \mathrm{~g}$ for $20 \mathrm{~min}$. Serum samples were stored at $-20^{\circ}$ until analysis. The liver and kidneys were also removed, weighed and stored at $-20^{\circ}$.

The compositions of the $\mathrm{Zn}$-deficient and control diets are shown in Table 1. The contents of $\mathrm{Zn}$ in the $\mathrm{Zn}$-deficient and control diets were 0.95 and $45 \mathrm{mg} / \mathrm{kg}$ diet respectively. All rats were given deionized water $a d$ lib.

\section{Zinc content}

A $1 \mathrm{~g}$ portion of each test diet, liver and kidney was heated for 48-72 $\mathrm{h}$ in a muffle oven at $450^{\circ}$. After the samples cooled, $2 \mathrm{ml} 1 \mathrm{M}-\mathrm{HCl}$ was added, and the digestates were heated and diluted with doubly-distilled deionized water. Serum was diluted 1:3 with the deionized water.

The concentration of stock $\mathrm{Zn}$ and sample solutions was measured by atomic absorption spectroscopy with a Hitachi 208 Atomic Absorption Spectrophotometer (Hitachi Ltd, Tokyo, Japan) at $213.8 \mathrm{~nm}$.

\section{Chemicals}

All chemicals used were analytical grade and were purchased from Nacalai Tesque (Kyoto, Japan) unless otherwise stated. $\mathrm{NADP}^{+}, 5,6$-dihydrouracil and $N$-carbamoyl- $\beta$-alanine were purchased from Sigma Chemical Co. (St. Louis, MO, USA). Glutamate dehydrogenase $(E C$ 1.4.1.3) was purchased from Boehringer Mannheim $\mathrm{GmbH}$ (Mannheim, Germany), and sodium phenyl phosphate from Wako Pure Chemical Industries, Ltd (Osaka, Japan). 5-Bromo-5,6-dihydrouracil was synthesized according to the method described by Zee-Cheng et al. (1961).

\section{Enzyme assays}

Dihydropyrimidinase. The liver was homogenized in 10 volumes of $10 \mathrm{~mm}$-potassium phosphate, pH 7.0, containing $10 \mathrm{~mm}$-2-mercaptoethanol. After centrifugation, the supernatant fraction was used for analysis of dihydropyrimidinase and $\beta$-ureidopropionase (EC 3.5.1.6) activities. 
Table 1. Composition of the diets $(\mathrm{g} / \mathrm{kg})$

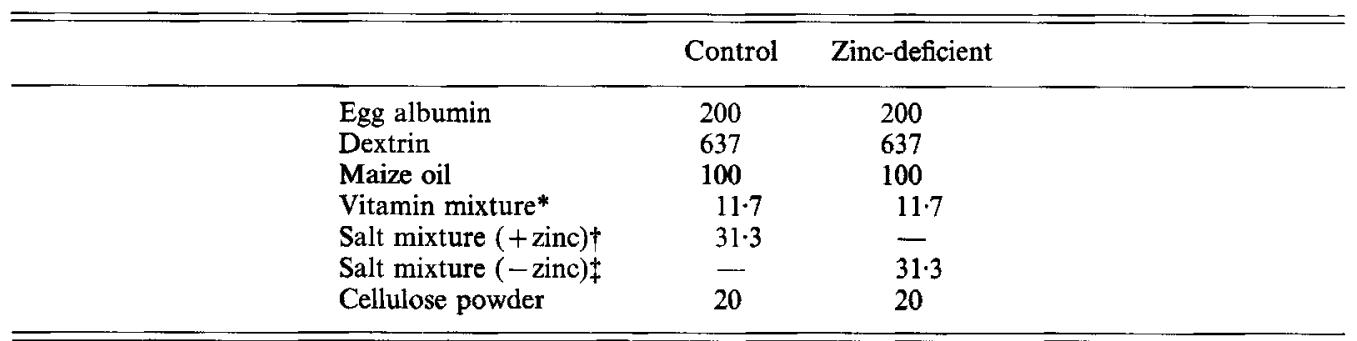

* Vitamins were $(\mathrm{mg} / \mathrm{kg}$ diet): retinyl acetate $2 \cdot 01$, cholecalciferol $0.03, \alpha$-tocopheryl acetate 58.5 , menadione $60 \cdot 8$, thiamine hydrochloride 14.0 , riboflavin $46 \cdot 8$, pyridoxine hydrochloride $9 \cdot 4$, cyanocobalamin $0 \cdot 006$, ascorbic acid 351 , D-biotin $0 \cdot 23$, pteroylglutamic acid $2 \cdot 34$, calcium pantothenate $58 \cdot 5$, p-aminobenzoic acid $58 \cdot 5$, niacin $70 \cdot 2$, choline chloride 2340.

† Minerals (+zinc) were (g/kg diet): $\mathrm{CaHPO}_{4} .2 \mathrm{H}_{2} \mathrm{O} 4 \cdot 557, \mathrm{KH}_{2} \mathrm{PO}_{4} 8 \cdot 050, \mathrm{NaH}_{2} \mathrm{PO}_{4} 2 \cdot 927, \mathrm{NaCl} 1 \cdot 459$ Ca-lactate 10.983, Fe-citrate 0.995, $\mathrm{MgSO}_{4} 2.244, \mathrm{ZnCO}_{3} 0.034, \mathrm{MnSO}_{4} .4 \sim 6 \mathrm{H}_{2} \mathrm{O} 0.038, \mathrm{CuSO}_{4} .5 \mathrm{H}_{2} \mathrm{O} 0009$, KI 0.003 .

$\$ \mathrm{ZnCO}_{3}$ was omitted from the above mixture.

Dihydropyrimidinase activity was determined by measuring the rate of decrease in absorbance associated with 5-bromo-5,6-dihydrouracil at $225 \mathrm{~nm}$ in a cuvette with a $1.0 \mathrm{~cm}$ light path at $37^{\circ}$ (Brooks et al. 1983). The standard reaction mixture contained $50 \mathrm{~mm}$-Tris$\mathrm{HCl}$ buffer, $\mathrm{pH} 8.2$, and $0.17 \mathrm{~mm}$-5-bromo-5,6-dihydrouracil in a total volume of $3.0 \mathrm{ml}$.

$\beta$-Ureidopropionase, $\beta$-Ureidopropionase activity was measured with respect to the rate of formation of $\mathrm{NH}_{3}$ (Tamaki et al. 1987). The standard reaction mixture contained $0 \cdot 1 \mathrm{M}$ - sodium phosphate, $\mathrm{pH} 7 \cdot 0$, including bovine serum albumin $(1 \mathrm{~g} / 1), 10 \mathrm{mM}-\mathrm{MgCl}_{2}$, $1 \mathrm{mM}$-EDTA, $5 \mathrm{~mm}$-2-mercaptoethanol and $2 \mathrm{mM}-N$-carbamoyl- $\beta$-alanine. Incubation was carried out in a shaking water bath for $30 \mathrm{~min}$ at $37^{\circ}$.

Dihydropyrimidine dehydrogenase. The liver was homogenized in 10 volumes of $10 \mathrm{~mm}-$

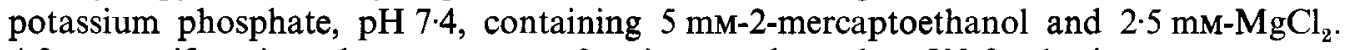
After centrifugation, the supernatant fraction was heated to $50^{\circ}$ for $1 \mathrm{~min}$

and then cooled to $4^{\circ}$. The precipitate was discarded after centrifugation and the supernatant fraction was adjusted to $\mathrm{pH} 4.85$ with acetic acid $(50 \mathrm{ml} / 1)$. After centrifugation, the supernatant fraction was neutralized with $0.5 \mathrm{M}-\mathrm{KOH}$ and treated with $\left(\mathrm{NH}_{4}\right)_{2} \mathrm{SO}_{4}$. The precipitate obtained at $30-50 \%$ saturation was dissolved in a minimum volume of the above buffer and used for enzyme analysis.

Dihydropyrimidine dehydrogenase ( $E C$ 1.3.1.1) activity was followed by measuring the rate of disappearance of NADPH at $37^{\circ}$ (Fritzson, 1960). The standard assay mixture

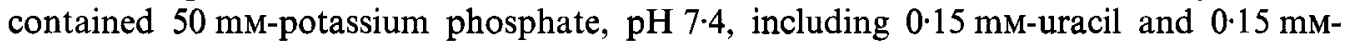
NADPH, in a total volume of $3.0 \mathrm{ml}$.

Alkaline phosphatase. Alkaline phosphatase (EC 3.1.3.1) activity was measured with respect to the rate of formation of phenol from sodium phenyl phosphate (Bessey et al. 1946). The absorbance at $405 \mathrm{~nm}$ was measured.

\section{Preparation of antiserum}

Purified dihydropyrimidinase $(0.7 \mathrm{mg})$ from rat liver was emulsified with an equal volume of Freund's complete adjuvant and injected subcutaneously twice into a rabbit at 2-week intervals. Two weeks after the second injection, $0.2 \mathrm{mg}$ of the enzyme was injected intravenously. The rabbit was bled 2 weeks after intravenous injection and the serum 
collected. Control serum was prepared from rabbits before the first injection of the purified enzyme.

\section{Immunodiffusion and immunoprecipitation}

Double immunodiffusion was performed in agar $(10 \mathrm{~g} / 1)$ in $20 \mathrm{~mm}$-potassium phosphate (pH 7·2).

In the immunological quantitation of dihydropyrimidinase, a total volume of $0.3 \mathrm{ml}$ (various amounts of sample solution and $5 \mu \mathrm{l}$ antiserum, adjusted to a fixed volume with $20 \mathrm{~mm}$-potassium phosphate, $\mathrm{pH} 7 \cdot 2$, containing $0.225 \mathrm{M}-\mathrm{KCl}$ ) was incubated for $30 \mathrm{~min}$ at $37^{\circ}$, then allowed to stand for $16 \mathrm{~h}$ at $4^{\circ}$. After addition of $0.3 \mathrm{ml}$ protein A-Sepharose CL$4 \mathrm{~B}$ suspended in phosphate-buffered saline $\left(4.0 \mathrm{~g} \mathrm{NaCl}, 0.1 \mathrm{~g} \mathrm{KCl}, 1.45 \mathrm{~g} \mathrm{Na}_{2} \mathrm{HPO}_{4} .12 \mathrm{H}_{2} \mathrm{O}\right.$ and $0.1 \mathrm{~g} \mathrm{KH}_{2} \mathrm{PO}_{4}$, in a total volume of $500 \mathrm{ml}$ by addition of $\mathrm{H}_{2} \mathrm{O}$ ), the reaction mixture was allowed to stand for $60 \mathrm{~min}$ at $25^{\circ}$, before a brief centrifugation. The supernatant fraction was assayed for hydropyrimidinase activity.

\section{Derivation of feed intake and body-weight change}

Feed intake data and body-weight change data were analysed by a modification of the 'Cosinor' method (Halberg et al. 1972). Feed intake $(F)$ or body-weight change $(\Delta B)$ at day $t$ was derived from the following equation:

$$
F(\text { or } \Delta B)=M+A \cos (2 \pi(t-\psi) / \tau),
$$

where $M, A, \tau$ and $\psi$ represent mesor (the rhythm-adjusted mean), amplitude (maximum or minimum value from the adjusted mean), period (the length of one complete cycle), and phase shift (time of maximum on the first cycle) respectively.

The experimental data obtained were fitted to the above equation by a nonlinear leastsquares method. The four parameters $M, A, \tau$ and $\psi$ were calculated in the analysis (Marquardt, 1963), and are given with standard errors, using a subroutine containing an SALS, a computer program which was developed by the computer centre at the University of Tokyo (Nakagawa \& Oyanagi, 1980).

\section{Protein measurement}

Protein concentration was measured with Folin phenol reagent (Lowry et al. 1951), using bovine serum albumin as a standard.

\section{Statistical analysis}

One-way analysis of variance was used to compare the groups. When a significant difference $(P<0.05)$ was found between groups, the statistical significance of difference between values was assessed by Student's $t$ test.

\section{RESULTS}

Body weight and feed intake of rats fed on zinc-deficient diets

The $\mathrm{Zn}$-deficient rats showed the typical symptoms of $\mathrm{Zn}$ deficiency such as alopecia, depigmentation of hair, dermatitis of the paws, and anorexia with growth retardation, which have been described by Wallwork et al. (1981). Fig. 1 shows the average weight gain in each group. The body weight of the control rats increased linearly under experimental conditions, while that of the $\mathrm{Zn}$-deficient animals was retarded in a cyclic pattern. The final weight gains of the rats fed on control and $\mathrm{Zn}$-deficient diets for 4 weeks were $144 \cdot 6$ (SE 5.3) and $38 \cdot 2$ (SE 2-3) g respectively.

The feed intake in the $\mathrm{Zn}$-deficient diet group was $64.1 \%$ of the intake in the control 


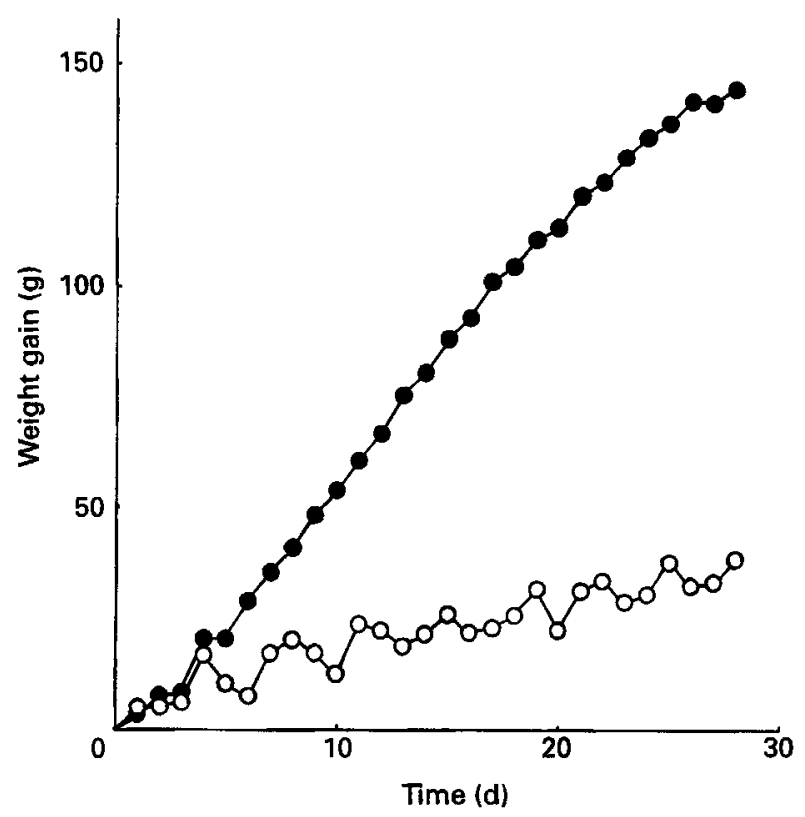

Fig. 1. Average weight gain over time in rats fed on a control diet $(O)$ or a zinc-deficient diet $(O)$.

group. Fig. 2a illustrates the cyclic feeding pattern of five $\mathrm{Zn}$-deficient rats, which has been described by others (Mills et al. 1969; Chesters \& Quarterman, 1970; Wallwork et al. 1981; Kramer et al. 1984). The values of the rhythmometric parameters obtained by Cosinor analysis are shown in Table 2 . There was a cyclic variation in feed intake in each of the five rats as well as in the group (Table 2 and Fig. 2). The cyclical period of the feed intake of the $\mathrm{Zn}$-deficient rats ranged from $3 \cdot 3$ to $3.6 \mathrm{~d}$, and the phase shift was from 0.7 to $1.3 \mathrm{~d}$.

The mean values of $M, A, \tau$ and $\psi$ for the five $\mathrm{Zn}$-deficient rats were calculated to be $10 \cdot 1$ (SE 0.4) $\mathrm{g} / \mathrm{d}, 3.5$ (SE 0.5) $\mathrm{g} / \mathrm{d}, 3.5$ (SE 0.1 ) d and 1.0 (SE 0.1 ) d respectively.

Cosinor analysis demonstrated that the pattern of body change over $28 \mathrm{~d}$ could also be fitted to a cosine wave with very high correlation (Fig. $2 \mathrm{~b}$ and Table 3 ). The period of the cycle ranged from 3.3 to $3.7 \mathrm{~d}$ and was closely related to that of the intake of the $\mathrm{Zn}$ deficient diet. However, the phase shift (time of maximum on the first cycle) of the cycle for body-weight change was $0.5 \mathrm{~d}$ shorter than that of the cycle for the feed intake. The calculated mean values of $M, A, \tau$ and $\psi$ for individual means in the $\mathrm{Zn}$-deficient rats were 1.4 (SE 0.1) g/d, $7.9($ SE $1 \cdot 3$ ) g/d, 3.5 (SE $0 \cdot 1) \mathrm{d}$ and 0.5 (SE $0 \cdot 1$ ) d respectively.

The acrophase of the cycle could be represented by the formula $2 \pi(\tau-\psi) / \tau$. The calculated mean values of acrophase for the cycle of feed intake and weight change were $(1.44 \pm 0.07) \pi$ and $(1.73 \pm 0.07) \pi$ radian respectively.

\section{Serum and liver zinc content in zinc-deficient rats}

The mean daily $\mathrm{Zn}$ intakes calculated from feed intake in the control and $\mathrm{Zn}$-deficient diet groups were 708 (SE 17) and 9.1 (SE 0.45) $\mu \mathrm{g}$ respectively. The serum $\mathrm{Zn}$ content showed a significant decrease during the course of the $\mathrm{Zn}$ depletion in the latter group. At 4 weeks the serum $\mathrm{Zn}$ contents in the two groups were 2.58 (SE 0.09) and 0.81 (SE 0.07) $\mathrm{mg} / \mathrm{ml}$ respectively $(P<0.01)$. The alkaline phosphatase activities in the serum of the rats fed on the control and Zn-deficient diets were 9.62 (SE 0.54) and 4.92 (SE 1.12) $\mathrm{nmol} / \mathrm{min}$ per $\mathrm{mg}$ protein respectively $(P<0.01)$. 

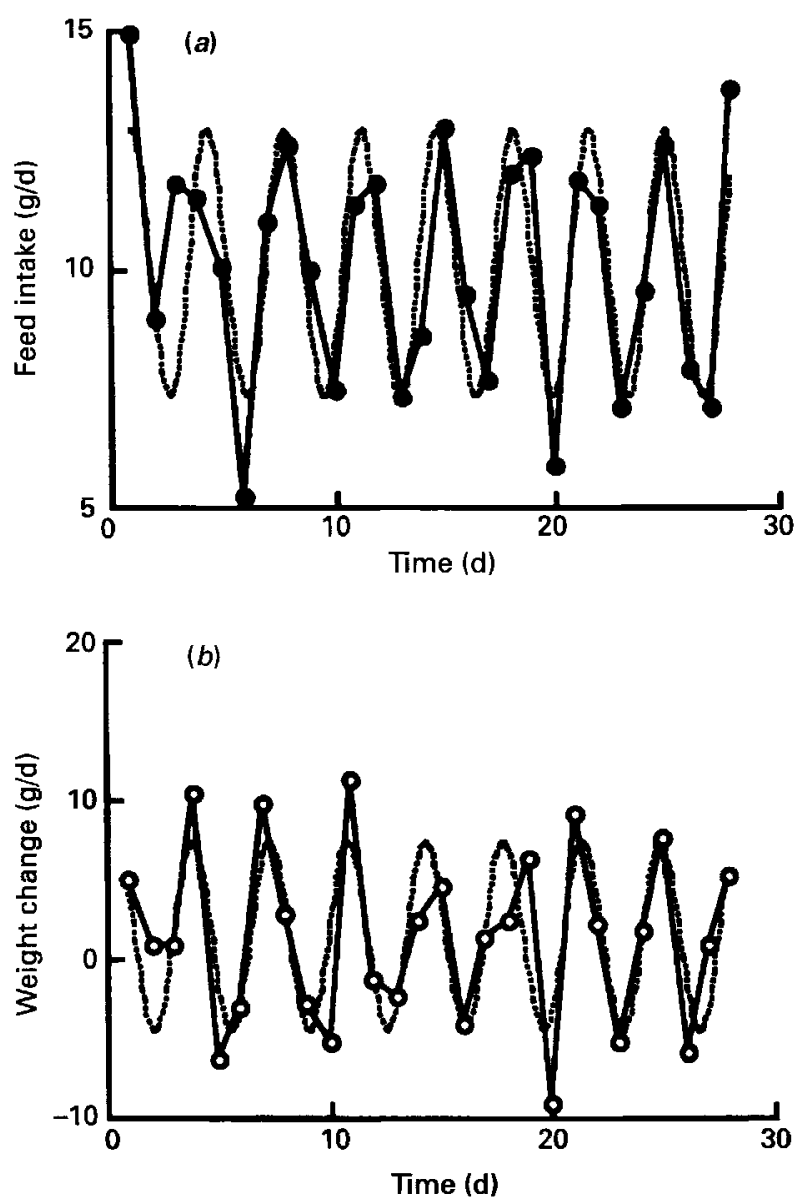

Fig. 2. Pattern of cyclic variation of feed intake $(a)$ and body-weight change $(b)$ of rats fed on a zinc-deficient diet. Each point represents the average feed intake $(a, O)$ or body-weight change $(b, O)$ for the previous $24 \mathrm{~h}$ period. All the data from five rats were analysed by the Cosinor method. (-- ), The curve with best fit obtained with computer-generated cosine curves. $F=10 \cdot 1+2 \cdot 8 \cos (2 \pi(t-1 \cdot 0) / 3 \cdot 4) . \Delta B=1 \cdot 4+5.9 \cos (2 \pi(t-0 \cdot 5) / 3 \cdot 5)$.

Table 2. Rhythmometric summary of Cosinor analysis of zinc-deficient-feed intake in the previous $24 \mathrm{~h}$ period of rats for $28 \mathrm{~d}$

(Values with their standard errors)

\begin{tabular}{|c|c|c|c|c|c|c|c|c|c|c|}
\hline \multirow[t]{2}{*}{ Rat... } & \multicolumn{2}{|c|}{ Rat 1} & \multicolumn{2}{|c|}{ Rat 2} & \multicolumn{2}{|c|}{ Rat 3} & \multicolumn{2}{|c|}{ Rat 4} & \multicolumn{2}{|c|}{ Rat 5} \\
\hline & Value & $\mathrm{SE}$ & Value & $\mathbf{S E}$ & Value & $\mathrm{SE}$ & Value & SE & Value & SE \\
\hline $\operatorname{Mesor}\left(M^{*}\right)(\mathrm{g} / \mathrm{d})$ & $10 \cdot 4$ & 0.2 & $11 \cdot 2$ & $1 \cdot 6$ & $9 \cdot 4$ & $0-1$ & $10 \cdot 2$ & 0.2 & $9 \cdot 2$ & 0.7 \\
\hline Amplitude $(A)(\mathrm{g} / \mathrm{d})$ & 4.5 & 0.3 & $3 \cdot 1$ & $2 \cdot 2$ & $3 \cdot 8$ & $0 \cdot 3$ & 1.6 & 0.3 & $4 \cdot 5$ & 0.9 \\
\hline Period $(\tau)(\mathrm{d})$ & $3 \cdot 4$ & $0 \cdot 1$ & $3 \cdot 6$ & $0 \cdot 5$ & $3 \cdot 3$ & $0 \cdot 1$ & $3 \cdot 5$ & $0 \cdot 1$ & $3 \cdot 5$ & $0 \cdot 1$ \\
\hline Phase shift $(\psi)(\mathrm{d})$ & $1 \cdot 3$ & $0 \cdot 1$ & 0.8 & 0.7 & $1 \cdot 2$ & $0 \cdot 1$ & 0.7 & 0.2 & 0.9 & 0.1 \\
\hline$R^{2}$ & \multicolumn{2}{|c|}{0.611} & \multicolumn{2}{|c|}{0.401} & \multicolumn{2}{|c|}{0.464} & \multicolumn{2}{|c|}{0.275} & \multicolumn{2}{|c|}{0.617} \\
\hline$P$ & \multicolumn{2}{|c|}{$<0.0001$} & \multicolumn{2}{|c|}{$<0.0005$} & \multicolumn{2}{|c|}{$<0-0001$} & \multicolumn{2}{|c|}{$<0.005$} & \multicolumn{2}{|c|}{$<0.0001$} \\
\hline
\end{tabular}

* Rhythm-adjusted mean.

Feed intake in the previous $24 \mathrm{~h}$ period at a $t$ day $(\mathrm{F}): F=M+A \cos (2 \pi(t-\psi) / \tau)$.

Time of maximum feed intake in the previous $24 \mathrm{~h}$ period (d) $=n \tau+\psi(n=0,1,2,3, \ldots)$.

Time of minimum feed intake in the previous $24 \mathrm{~h}$ period $(\mathrm{d})=(n+1 / 2) \tau+\psi(n=0,1,2,3, \ldots)$. 
Table 3. Rhythmometric summary of Cosinor analysis of weight change in the previous $24 \mathrm{~h}$ period of rats fed on a zinc-deficient diet for $28 \mathrm{~d}$

(Values with their standard errors)

\begin{tabular}{|c|c|c|c|c|c|c|c|c|c|c|}
\hline \multirow[t]{2}{*}{ Rat... } & \multicolumn{2}{|c|}{ Rat 1} & \multicolumn{2}{|c|}{ Rat 2} & \multicolumn{2}{|c|}{ Rat 3} & \multicolumn{2}{|c|}{ Rat 4} & \multicolumn{2}{|c|}{ Rat 5} \\
\hline & Value & SE & Value & SE & Value & SE & Value & SE & Value & SE \\
\hline $\operatorname{Mesor}\left(M^{*}\right)(\mathrm{g} / \mathrm{d})$ & $1 \cdot 4$ & 0.2 & $1 \cdot 7$ & $0-2$ & 0.9 & $0 \cdot 2$ & 1.4 & $0 \cdot 2$ & $1 \cdot 4$ & 0.2 \\
\hline Amplitude $(A)(\mathrm{g} / \mathrm{d})$ & $7 \cdot 8$ & 0.3 & $9 \cdot 1$ & $0-3$ & $10 \cdot 1$ & 0.3 & $3 \cdot 1$ & $0 \cdot 3$ & $9 \cdot 5$ & $0 \cdot 3$ \\
\hline Period $(\tau)(d)$ & $3 \cdot 4$ & $0 \cdot 1$ & 3.7 & 0.1 & $3 \cdot 3$ & 0.1 & 3.5 & 0.1 & $3 \cdot 5$ & $0 \cdot 1$ \\
\hline Phase shift $(\psi)(\mathrm{d})$ & 0.8 & 0.05 & $0 \cdot 3$ & $0 \cdot 03$ & 0.7 & 0.03 & 0.2 & $0 \cdot 11$ & 0.4 & $0 \cdot 04$ \\
\hline$R^{2}$ & \multicolumn{2}{|c|}{0.479} & \multicolumn{2}{|c|}{$0 \cdot 401$} & \multicolumn{2}{|c|}{0.430} & \multicolumn{2}{|c|}{0.163} & \multicolumn{2}{|c|}{0.653} \\
\hline$P$ & \multicolumn{2}{|c|}{$<0.0001$} & \multicolumn{2}{|c|}{$<0.0005$} & \multicolumn{2}{|c|}{$<0.0002$} & \multicolumn{2}{|c|}{$<0.05$} & \multicolumn{2}{|c|}{$<0.0001$} \\
\hline
\end{tabular}

* Rhythm-adjusted mean.

Weight change in the previous $24 \mathrm{~h}$ period at a $t$ day $(\Delta B): \Delta B=M+A \cos (2 \pi(t-\psi) / \tau)$.

Time of maximum weight change in the previous $24 \mathrm{~h}$ period $(\mathrm{d})=n \tau+\psi(n=0,1,2,3 \ldots)$.

Time of minimum weight change in the previous $24 \mathrm{~h}$ period $(\mathrm{d})=(n+1 / 2) \tau+\psi(n=0,1,2,3 \ldots)$.

(a)

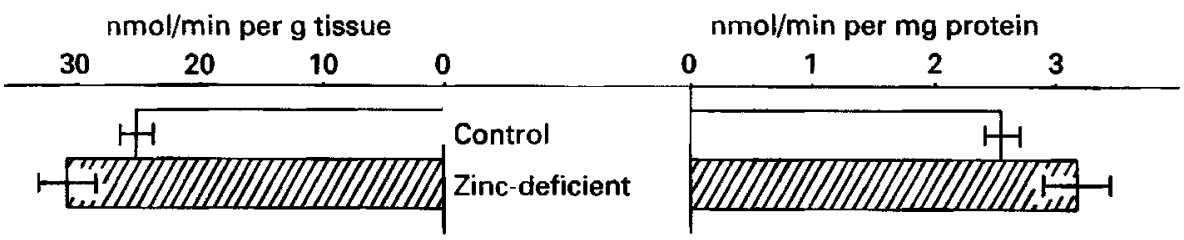

(b)

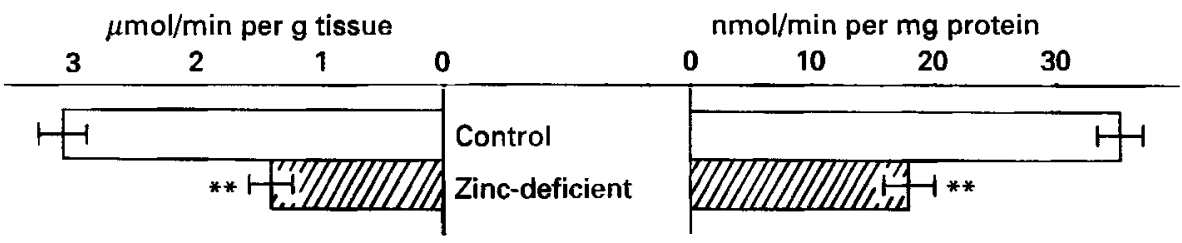

(c)

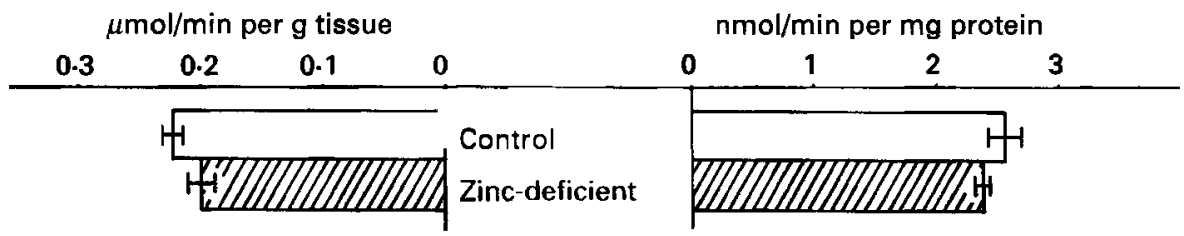

Fig. 3. Effect of a zinc-deficient diet on the activities of rat liver pyrimidine-metabolizing enzymes: (a) dihydropyrimidine dehydrogenase $(E C$ 1.3.1.1), (b) dihydropyrimidinase $(E C$ 3.5.2.2) and (c) $\beta$-ureidopropionase ( $E C$ 3 5.1 .6$)$. The protein concentration in the precipitate obtained at 30-50\% ammonium sulphate saturation $(a)$ and in the supernatant fraction after centrifugation of the homogenate $(b$ and $c$ ) was estimated as described on p. 714. Values are means with their standard errors indicated by vertical bars. ( $\square$ ), Control group; $(\square)$, zinc-deficient group. ${ }^{* *}$ Mean value was significantly different from that of the control group, $P<0.01$. 


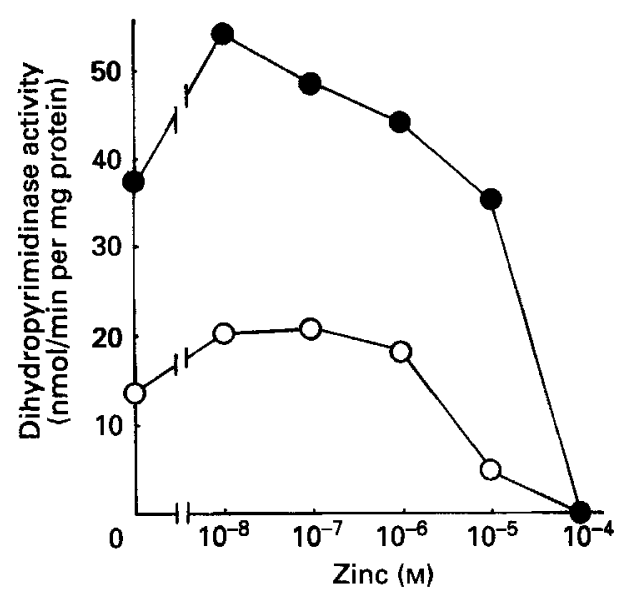

Fig. 4. Effect of addition of exogenous zinc on rat liver dihydropyrimidinase (EC 3.5.2.2) activity in vitro. Rat liver ( $1 \mathrm{~g}$ tissue, $0.2 \mathrm{~g}$ from each of five different rats) was homogenized in $10 \mathrm{ml} 10 \mathrm{~mm}$-potassium phosphate, $\mathrm{pH} 7.0$, containing $10 \mathrm{~mm}-2$-mercaptoethanol. The homogenate was centrifuged for $20 \mathrm{~min}$ at $27000 \mathrm{~g}$. The supernatant fraction was used as sample solution. The enzyme activity was assayed by exogenous addition of $\mathrm{Zn}\left(\mathrm{NO}_{3}\right)_{2}$ at the indicated zinc concentration. (O), Control group; $(\mathrm{O})$, zinc-deficient diet group.

The liver $\mathrm{Zn}$ level in contrast to the serum level, was not markedly affected by the $\mathrm{Zn}$ deficient diet. The mean $\mathrm{Zn}$ contents of the liver at 4 weeks in the control and $\mathrm{Zn}$-deficient groups were 19.52 (SE 1.34) and 16.42 (SE 0.85) $\mu \mathrm{g} / \mathrm{g}$ tissue respectively.

\section{Effect of zinc-deficient diet on pyrimidine-catabolizing enzymes}

Fig. 3 shows the activities of dihydropyrimidine dehydrogenase, dihydropyrimidinase and $\beta$-ureidopropionase in the control and $\mathrm{Zn}$-deficient groups. Of these three enzymes in the rat liver, dihydropyrimidinase activity was significantly decreased by the $\mathrm{Zn}$-deficient diet. However, the activities of these enzymes in the kidney were not affected by the Zn-deficient diet (results not shown).

When the value of $\cos (2 \pi(t-\psi) / \tau))$ at day 28 in the formula of the feed intake in rats fed on the $\mathrm{Zn}$-deficient diet was simulated, we could not find any relationship between the cosine value and the liver dihydropyrimidinase activity. These results suggest that dihydropyrimidinase activity in liver of $\mathrm{Zn}$-deficient rats has no cyclic variation.

\section{Effect of exogenous addition of zinc on dihydropyrimidinase activity}

Fig. 4 shows the effect of exogenous $\mathrm{Zn}$ addition on rat liver dihydropyrimidinase activity. After addition of $10 \mathrm{nM}-\mathrm{Zn}$ to liver crude extract from control and $\mathrm{Zn}$-deficient rats, the dihydropyrimidinase activity showed 1.44- and 1.50-fold activation respectively, compared with that without $\mathrm{Zn}$ addition. However, a high concentration of $\mathrm{Zn}(0.1 \mathrm{~mm})$ completely inactivated the enzyme in both the control and Zn-deficient groups.

\section{Quantitation of antigen by immunotitration}

The antiserum to rat liver dihydropyrimidinase produced a single connecting band of precipitin between purified dihydropyrimidinase and crude extract from rat liver (Ouchterlony double diffusion). The antiserum inhibited enzyme activity of the crude extracts from control and $\mathrm{Zn}$-deficient rat liver. The quantitative immunotitration results are shown in Fig. 5. It can be seen that the equivalence points for the titrations were $0.26 \mathrm{mg}$ and $0.52 \mathrm{mg}$ of crude extract from control and $\mathrm{Zn}$-deficient rat liver respectively, per $5 \mu \mathrm{l}$ 


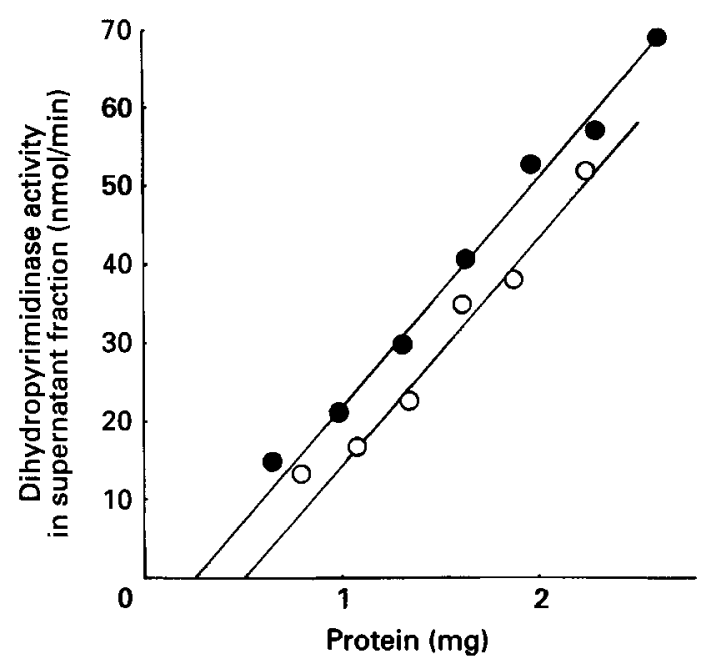

Fig. 5. Immunological quantitation of dihydropyrimidinase ( $E C$ 3.5.2.2) activity in zinc-deficient and control rat liver supernatant fractions. Rat liver ( $1 \mathrm{~g}$ tissue, $0 \cdot 2 \mathrm{~g}$ from each of five different rats) was homogenized in 10 volumes of $10 \mathrm{~mm}$-potassium phosphate, $\mathrm{pH} \mathrm{7.0,} \mathrm{containing} 10 \mathrm{~mm}$-2-mercaptoethanol. The homogenate was centrifuged for $20 \mathrm{~min}$ at $27000 \mathrm{~g}$. The supernatant fraction was used as sample solution. The specific activities of dihydropyrimidinase in samples from control and zinc-deficient rat liver were 32.4 and $12.6 \mathrm{nmol} / \mathrm{min} \mathrm{per} \mathrm{mg}$ protein respectively. After titration with antiserum, the supernatant fluids were assayed for dihydropyrimidinase activity. (O), Control group; $(\bigcirc)$, zinc-deficient group.

antibody. It can be calculated that $1 \mu \mathrm{l}$ antiserum titrated $1.7 \mathrm{nmol} / \mathrm{min}$ dihydropyrimidinase in the liver from control as well as $\mathrm{Zn}$-deficient rats.

\section{DISCUSSION}

In the present study the young male rats fed on a $\mathrm{Zn}$-deficient diet showed the typical signs of $\mathrm{Zn}$ deficiency, including anorexia with marked decrease of growth compared with control rats. This reduction in feed intake was previously reported to be accompanied by a pattern of cyclic feeding in rats with Zn-deficient diet (Mills et al. 1969; Chesters \& Quarterman, 1970; Chesters \& Will, 1973; Wallwork et al. 1981; Gingliano \& Millward, 1984; Kramer et al. 1984; Quinn et al. 1990). Here, we found by Cosinor analysis that the period of the cycle was 3.5 (SE 0.1) d. These results suggest that rats fed on $\mathrm{Zn}$-deficient diet show little variation in feeding pattern, which consistently shows a cycle of $3 \cdot 5 \mathrm{~d}$.

When the feed intake of rats is examined at $2 \mathrm{~h}$ intervals throughout the day, $\mathrm{Zn}$-deficient rats are found to eat on fewer occasions than control rats (Chesters \& Will, 1973). However, during those $2 \mathrm{~h}$ periods when the $\mathrm{Zn}$-deficient rats did eat, the quantities eaten in $2 \mathrm{~h}$ showed the same weight distribution as those for the $\mathrm{Zn}$-adequate rats (Chesters \& Will, 1973). When we examined the cycle of feed intake and body-weight change of Zndeficient rats for each $24 \mathrm{~h}$ period throughout the 4-week study, we found both had a $3 \cdot 5$ (SE $0 \cdot 1) \mathrm{d}$ period of the cycle by computer Cosinor analysis.

$\mathrm{Zn}$ deficiency impairs growth by a combination of reduced feed intake, reduced anabolic response to feed, and increased catabolic response to the reduced intake in which corticosterone may play a role (Gingliano \& Millward, 1987). Recently, it was proposed that the growth retardation seen in $\mathrm{Zn}$-deficient states may be mediated through reduced serum-insulin-like growth factor-1 production (Dorup et al. 1991). However, we could not account for the $3.5 \mathrm{~d}$ cycle of feed intake and body change through these effectors.

The period of the cycle of feed intake was in good agreement with that of the body- 
weight change. However, we found marked differences between the amplitudes of the cycle. The feed intake values are for essentially dry weights of diet whereas the body-weight changes represent differences in wet weight. If the tissues being lost and gained in a cyclical manner contain, say, $80 \%$ or more water, the differences could largely be explained on this basis. In fact, daily intakes of water and feed are closely correlated for the $\mathrm{Zn}$-deficient rats (Wallwork et al. 1981). Therefore, the amplitude in body weight may be about twice that in feed intake.

Dihydropyrimidinase is a $\mathrm{Zn}$-metalloenzyme, containing four tightly bound $\mathrm{Zn}$ ions per molecule of active enzyme (Brooks et al. 1971, 1983). The Zn-deficient diet significantly inactivated dihydropyrimidinase in liver with a reduction of the enzyme protein. However, the activity of $\beta$-ureidopropionase, which contains two putative $\mathrm{Zn}$-binding site motifs (Kvalnes-Krick \& Traut, 1993), was maintained at the control level in the rats fed on the $\mathrm{Zn}$-deficient diet, while dihydropyrimidine dehydrogenase activity showed a slight increase. These results suggest that rat liver dihydropyrimidinase activity is more strongly affected by $\mathrm{Zn}$ deficiency than is $\beta$-ureidopropionase. Since protein synthesis and RNA concentration are reduced in the Zn-deficient rat (Gingliano \& Millward, 1987), dihydropyrimidinase may be regulated only under physiological $\mathrm{Zn}$ conditions.

The rate-limiting enzyme in pyrimidine catabolism in the rat liver is dihydropyrimidine dehydrogenase (Canellakis, 1956; Fritzson, 1957). However, in normal human extrahepatic tissues, dihydropyrimidinase, rather than dihydropyrimidine dehydrogenase, is the ratelimiting enzyme in the pyrimidine base catabolic pathway (Naguib et al. 1985). The dihydropyrimidinase level in solid tumours is increased compared with that in normal tissues (Naguib et al. 1985). During the catabolism of 5-fluorouracil in isolated rat hepatocytes, the predominant metabolite is 5-fluoro-5,6-dihydrouracil (Sommadossi et al. 1982), and the rate-limiting step which has been identified by a mathematical model of the kinetics is the degradation of 5-fluorodihydrouracil (Mentre et al. 1984). These findings suggest that dihydropyrimidinase has an important function in pyrimidine metabolism.

The active form of dihydropyrimidinase from rat liver contains four $\mathrm{Zn}$ ions per molecule, presumably at the ratio of one per subunit (Brooks et al. 1979, 1983; Kikugawa et al. 1994). The $\mathrm{Zn}$ can be removed by incubation with chelators, and the enzyme activity can be restored by incubation of the apoenzyme with $5 \mu \mathrm{M}-\mathrm{Zn}$ (Brooks et al. 1983). However, $\mathrm{Zn}$ also acts as an irreversible inhibitor with a $K_{\mathrm{i}}$ of $23 \cdot 1 \mu \mathrm{M}$ (Kikugawa et al. 1994). Therefore, $\mathrm{Zn}$ acts as an inhibitor as well as an activator of the enzyme in vitro. The total level of $\mathrm{Zn}$ in the liver was calculated to be $0.3 \mathrm{~mm}$. However most of the $\mathrm{Zn}$ present in vivo is tightly bound and its concentration is little altered by $\mathrm{Zn}$ deficiency. Therefore, it is impossible that $\mathrm{Zn}$ acts as an inhibitor of dihydropyrimidinase under physiological conditions.

The immunological analysis revealed that both the activity and the protein concentration of dihydropyrimidinase in the liver of rats fed on the $\mathrm{Zn}$-deficient diet were lower than those of control rats. The addition of $\mathrm{Zn}$ to the extact from $\mathrm{Zn}$-deficient rat liver did not increase the activation to the control level. These results indicate that the level of apo-form of the enzyme is not increased in the $\mathrm{Zn}$-deficient rat and that the total enzyme protein may be regulated by $\mathrm{Zn}$. Nevertheless, the function of $\mathrm{Zn}$ in dihydropyrimidinase concentration requires further detailed study.

\section{REFERENCES}

Bessey, O. A., Lowry, O. H. \& Brock, M. J. (1946). A method for rapid determination of alkaline phosphatase with 5 cubic millimeters of serum. Journal of Biological Chemistry 164, 321-329.

Brooks, K. P., Jones, E. A., Kim, B.-D. \& Sander, E. G. (1983). Bovine liver dihydropyrimidine amidohydrolase; purification, properties and characterization as a zinc metalloenzyme. Archives of Biochemistry and Biophysics 226, 469-483. 
Brooks, K. P., Kim, B.-D. \& Sander, E. G. (1979). Dihydropyrimidine amidohydrolase is a zinc metalloenzyme. Biochimica et Biophysica Acta 570, 213-214.

Canellakis, E. S. (1956). Pyrimidine metabolism. I. Enzymatic pathways of uracil and thymine degradation. Journal of Biological Chemistry 221, 315-322.

Chesters, J. K. \& Quarterman, J. (1970). Effects of zinc deficiency on food intake and feeding patterns of rats. British Journal of Nutrition 24, 1061-1069.

Chesters, J. K. \& Will, M. (1973). Some factors controlling food intake by zinc-deficient rats. British Journal of Nutrition 30, 555-566.

Dorup, I., Flyvbjerg, A., Everts, M. A. \& Clausen, T. (1991). Role of insulin-like growth factor-1 and growth hormone in growth inhibition induced by magnesium and zinc deficiencies. British Journal of Nutrition 66, $505-521$.

Droke, E. A., Spears, J. W., Armstrong, J. D., Kegley, E. B. \& Simpson, R. B. (1993). Dietary zinc affects serum concentrations of insulin and insulin-like growth factor I in growing lambs. Journal of Nutrition 123, $13-19$.

Fritzson, P. (1957). The catabolism of $C^{14}$-labeled uracil, dihydrouracil, and $\beta$-ureidopropionic acid in rat liver slices. Journal of Biological Chemistry 226, 223-228.

Fritzson, P. (1960). Properties and assay of dihydrouracil dehydrogenase of rat liver. Journal of Biological Chemistry 235, 719-725.

Gingliano, R. \& Millward, D. J. (1984). Growth and zinc homeostasis in the severely Zn-deficient rat. British Journal of Nutrition 52, 545-560.

Gingliano, R. \& Millward, D. J. (1987). The effects of severe zinc deficiency on protein turnover in muscle and thymus. British Journal of Nutrition 57, 139-155.

Golden, B. E. (1988). Zinc in cell division and tissue growth: physiological aspects. In Zinc in Human Biology, pp. 119-128 [C. F. Mills, editor]. Berlin: Springer Verlag.

Halberg, F., Johnson, E. A., Nelson, W., Runge, W. \& Sothern, R. (1972). Autorhythmometry-procedures for physiologic self-measurements and their analysis. Physiology Teacher 1, 1-11.

Kautz, J. \& Schnackerz, K. D. (1989). Purification and properties of 5,6-dihydropyrimidine amidohydrolase from calf liver. European Journal of Biochemistry 181, 431-435.

Kikugawa, M., Kaneko, M., Fujimoto-Sakata, S., Maeda, M., Kawasaki, K., Takagi, T. \& Tamaki, N. (1994). Purification, characterization and inhibition of dihydropyrimidinase from rat liver. European Journal of Biochemistry 219, 393-399.

Kramer, T. R., Briske-Anderson, M., Johnson, S. B. \& Holman, R. T. (1984). Influence of reduced food intake on polyunsaturated fatty acid metabolism in zinc-deficient rats. Journal of Nutrition 114, 1224-1230.

Kvalnes-Krick, K. L. \& Traut, T. W. (1993). Cloning, sequencing, and expression of a cDNA encoding $\beta$-alanine synthase from rat liver. Journal of Biological Chemistry 268, 5686-5693.

Lee, M. H., Cowling, R. A., Sander, E. G. \& Pettigrew, D. W. (1986). Bovine liver dihydropyrimidine amidohydrolase: $\mathrm{pH}$ dependencies of inactivation by chelators and steady-state kinetic properties. Archives of Biochemistry and Biophysics 248, 368-378.

Lee, M. H., Pettigrew, D. W., Sander, E. G. \& Nowak, T. (1987). Bovine liver dihydropyrimidine amidohydrolase: $\mathrm{pH}$ dependencies of the steady-state kinetic and proton relaxation rate properties of the $\mathrm{Mn}$ (II)-containing enzyme. Archives of Biochemistry and Biophysics 259, 597-604.

Lowry, O. H., Rosebrough, N. J., Farr, A. L. \& Randall, R. J. (1951). Protein measurement with the Folin phenol reagent. Journal of Biological Chemistry 193, 265-275.

Maguire, J. H. \& Dudley, K. H. (1978). Partial purification and characterization of dihydropyrimidinase from calf and rat liver. Drug Metabolism and Disposition 6, 601-605.

Marquardt, D. W. (1963). An algorithm for least-squared estimation of nonlinear parameters. Journal of the Society for Industrial and Applied Mathematics 11, 431-441.

Mentre, F., Steimer, J.-L., Sommadossi, J.-P., Diasio, R. B. \& Cano, J.-P. (1984). A mathematical model of the kinetics of 5-fluorouracil and its catabolites in freshly isolated rat hepatocytes. Biochemical Pharmacology 33, 2727-2732.

Mills, C. F., Quarterman, J., Chesters, J. K., Williams, R. B. \& Dalgarno, A. G. (1969). Metabolic role of zinc. American Journal of Clinical Nutrition 22, 1240-1249.

Naguib, F. N. M., el Kouni, M. H. \& Cha, S. (1985). Enzymes of uracil catabolism in normal and neoplastic human tissues. Cancer Research 45, 5405-5412.

Nakagawa, T. \& Oyanagi, Y. (1980). Program system SALS for nonlinear least squares fitting in experimental sciences. In Recent Development in Statistical Inference and Data Analysis, pp. 221-225. [K. Matsushita, editor]. Amsterdam: North-Holland Publishing Co.

Quinn, P. B., Cremin, F. M., O'Sullivan, V. R., Hewedi, F. M. \& Bond, R. J. (1990). The influence of dietary folate supplementation on the incidence of teratogenesis in zinc-deficient rats. British Journal of Nutrition 64, 233-243.

Sommadossi, J.-P., Gewirtz, D. A., Diasio, R. B., Aubert, C., Cano, J.-P. \& Goldman, I. D. (1982). Rapid catabolism of 5-fluorouracil in freshly isolated rat hepatocytes as analyzed by high performance liquid chromatography. Journal of Biological Chemistry 257, 8171-8176.

Tamaki, N., Mizutani, N., Kikugawa, M., Fujimoto, S. \& Mizota, C. (1987). Purification and properties of $\beta$ ureidopropionase from the rat liver. European Journal of Biochemistry 169, 21-26. 
Wallach, D. P. \& Grisolia, S. (1957). The purification and properties of hydropyrimidine hydrase. Journal of Biological Chemistry 226, 277-288.

Wallwork, J. C., Fosmire, G. J. \& Sandstead, H. H. (1981). Effect of zinc deficiency on appetite and plasma amino acid concentrations in the rat. British Journal of Nutrition 45, 127-136.

Williams, R. B. \& Mills, C. F. (1970). The experimental production of zinc deficiency in the rat. British Journal of Nutrition 24, 989-1003.

Zee-Cheng, K.-Y., Robins, R. K. \& Cheng, C. C. (1961). Pyrimidines. III. 5,6-Dihydropyrimidines. Journal of Organic Chemistry 26, 1877-1884. 